\title{
From green technology development to green innovation: inducing regulatory adoption of pathogen detection technology for sustainable forestry
}

\author{
Jeremy Hall • Stelvia Matos • Vernon Bachor
}

Accepted: 30 June 2017 / Published online: 3 October 2017

(C) The Author(s) 2017. This article is an open access publication

\begin{abstract}
Technological entrepreneurship has been widely acknowledged as a key driver of modern industrial economies, and more recently, a panacea for environmental and social problems. However, our current understanding of how green-technology ventures emerge and diffuse more sustainable innovations remains limited. We advance theory on green entrepreneurship by drawing on institutional work to refine and extend our understanding of how entrepreneurs may influence government policies and practices in their attempts to diffuse green technology. We develop a theoretical framework that combines institutional work with a search tool, the technological, commercial,
\end{abstract}

Electronic supplementary material The online version of this article (https://doi.org/10.1007/s11187-017-9940-0) contains supplementary material, which is available to authorized users.

J. Hall $(\bowtie) \cdot$ S. Matos

Nottingham University Business School, Jubilee Campus, University of Nottingham, Nottingham NG8 1BB, UK e-mail: jeremy.hall@nottingham.ac.uk

URL: http://www.nottingham.ac.uk/business/ICCSR/ people.php? $\mathrm{p}=273$

S. Matos

e-mail: Stelvia.Matos@nottingham.ac.uk

V. Bachor

Business Administration Department, College of Business,

Winona State University, Somsen Hall 324E, 175 West Mark St., Winona, MN 55987, USA

e-mail: VBachor@winona.edu

URL: http://www.winona.edu/businessadmin/vernon-bachor.asp organizational, and societal (TCOS) framework of innovative uncertainties, which identifies key opportunities, hurdles, and potential unintended consequences at early stages of technology development. We present a detailed case study of a potential university-based green-tech venture developing pathogen detection technology for forestry protection. Foreign pathogens spread by international trade can have major detrimental impacts on forests and the industries that rely on them. Our analysis found that green technology demonstrating technological feasibility is necessary but not sufficient; green-tech ventures must also engage in institutional work, in this case, articulating the technology's benefits to regulators to establish legitimacy and avoid misuse that can hinder its adoption. We thus add to previous studies by emphasizing that institutional work could be a main activity for a green-tech venture, a core entrepreneurial strategy rather than an afterthought.

Keywords Green entrepreneurship · Green innovation . Institutional work · Regulatory technology adoption . Sustainable forestry $\cdot$ Technology development

\section{Introduction}

Since at least Schumpeter (1934), entrepreneurship has been widely acknowledged as a key driver of economic growth, where new technologies can disrupt old economic systems through creative destruction, a difficult 
and expensive process of throwing out the old in favor of the new. Entrepreneurship scholars have since identified creative destruction as a driver of more sustainable societies (Cohen and Winn 2007; Hockerts and Wüstenhagen 2010; York and Venkataraman 2010). While such a "green wave" of creative destruction sounds conceptually appealing, until recently, few studies from the entrepreneurship discourse have explored how this may emerge (Hörisch et al. 2017). According to Hall et al. (2010, p. 441), green entrepreneurship research has been primarily driven from outside entrepreneurship journals, noting "The unstated assumption is that green, clean, and low carbon entrepreneurs will somehow cure most of what ails aging industrial economies", what they call the panacea hypothesis. Hörisch et al. (2017, p. 48) note "This slight attention research has paid to the determinants of environmental entrepreneurship is surprising, given the potential of the concept to successfully address global environmental problems". Meyskens and Carsrud (2013, p. 740) specifically recommend further research on green-tech ventures, i.e., firms that "employ sustainable entrepreneurial practices to develop and commercialize technology that alleviates environmental market failures, preserves natural resources, and protects the environment."

We respond to these calls for further research by examining a detailed case of a potential green-tech venture in the form of a university spin-off, a type of firm created to commercially exploit university knowledge (Pirnay and Surlemont 2003). The venture is developing new genomics-based pathogen detection technology for forestry protection. Invasive pathogens can have catastrophic impacts on forests and the industries that rely on them. The technology offers significant improvements over the visual inspections currently used by regulators to detect foreign pathogens (Hall et al. 2014b). Although many studies investigate how regulations shape technology diffusion, much less attention explores how regulators adopt new technologies for their own needs (Hall et al. 2014b). According to Carpenter (2004), government regulators often favor better known firms, which may place new university spin-offs at a disadvantage over established firms. The key challenges are therefore less about "green technology development" but rather the broader "green innovation" process of successful commercialization and diffusion.

Inducing institutional change has been explored through "institutional work," "the purposive action of individuals and organizations aimed at creating, maintaining and disrupting institutions" (Lawrence and Suddaby 2006, p. 215), in our case, regulatory adoption of more effective pathogen detection technology. According to Lawrence and Dover (2015, p. 375), institutional work uses “...heterogeneous material and symbolic resources, the availability and quality of which can significantly affect the strategies actors employ." Here, we suggest purposive action is establishing legitimacy for the proposed pathogen detection technology, which is based on its ability to protect forests more effectively than incumbent methods.

Our aim is to advance theory on green entrepreneurship by drawing on institutional work to refine and extend our understanding of how entrepreneurs engage in purposive action to diffuse more sustainable technology. Our research question is thus: How can entrepreneurs engage in institutional work to facilitate the adoption of green technology, thus resulting in green innovation?

To answer this question, we develop a theoretical framework that combines institutional work with the "technological, commercial, organizational, and societal (TCOS)" framework of innovative uncertainties (Hall and Martin 2005; Hall et al. 2011, 2014a). TCOS is an organizing framework that explicitly searches for key technological, commercial, organizational, and societal issues to be overcome before an invention can result in successful innovation. It differs from other approaches by emphasizing that various stakeholders may use different heuristics to form opinions and make decisions. Thus, this framework helps to understand how entrepreneurs can induce changes to regulators' risk assessment practices through more effective green technology.

The TCOS analysis found that, in addition to demonstrating technological efficacy, there are also nontechnical challenges such as how information from the tests should be interpreted and used by regulators, the potential impact on international trade, and cost concerns from industry. Our analysis thus suggests that, while demonstrating technological feasibility is necessary, it may be insufficient; in order for successful green innovation to occur, the proposed green-tech venture must also provide advice regarding where the technology can be used and be prepared to address stakeholder concerns. It thus needs to engage in institutional work to articulate the technology's benefits to regulators to establish legitimacy and avoid misuse that can hinder its adoption. 
Next, we discuss the recent literature on entrepreneurship for sustainable development and institutional work that shape new green-tech ventures. We then present our methodology, followed by our analysis, discussion, and conclusion with recommendations.

\section{Theory development}

Sustainability concerns have become a major topic within the academic discourse. For example, the recent "Grand Challenges" literature calls for management scholars to find solutions for the UN Sustainable Development Goals (SDG), where Grand Challenges are defined as "...formulations of global problems that can be plausibly addressed through coordinated and collaborative effort" (George et al. 2016, p. 1880). Although entrepreneurship and innovation are explicitly seen as mechanisms to achieve SDGs (e.g., Goal 8: Decent Work and Economic Growth and Goal 9: Industry, Innovation, and Infrastructure), sustainable development has drawn limited attention within the entrepreneurship literature (Hall et al. 2010; Hörisch et al. 2017).

Seminal studies from the entrepreneurship literature regard environmental problems as market imperfections, where alert entrepreneurs can find profitable solutions to resolve these imperfections (Cohen and Winn 2007; Dean and McMullen 2007). These earlier studies thus emphasize opportunities for environmental entrepreneurs by creating new firms, markets, products, information sources, and institutions (York and Venkataraman 2010) as a panacea for societal problems (Hall et al. 2010).

Two additional themes within the entrepreneurship discourse discussed next are the role of policy (both as a supporting mechanism and hindrance to transformation) and the role of technological innovation. The role of policy includes a theoretical overview of policies for green entrepreneurship and institutional work as a means to induce regulatory change, and the role of technological innovation specifically focuses on mechanisms that green-tech ventures can use to identify key issues facilitating or hindering the technology's diffusion.

\subsection{The role of policy and institutional work}

Criscuolo and Menon (2015) and Kesidou and Demirel (2012) found that policy makers stimulate green entrepreneurship in both upstream (e.g., grants, research and development (R\&D) support) and downstream activities (e.g., regulation and deployment policies, tax mechanisms). Consistent with the market imperfections literature, others note that policy can also hinder green entrepreneurship, where transitioning towards sustainability requires regulatory change (Musiolik et al. 2012; Penna and Geels 2012). Institutional work (Lawrence and Suddaby 2006) is recognized as one strategy to invoke institutional change, thus potentially facilitating transition towards sustainability (Farla et al. 2012; Markard et al. 2012).

A key challenge recognized within the entrepreneurship literature is how entrepreneurs navigate the institutional environment (Bruton et al. 2010). Within the green entrepreneurship literature, Pacheco et al. (2010, p. 465) argue that green-tech ventures should generate communal institutions to "improve the competitiveness of sustainable behaviors." Drawing on entrepreneurial cooperation cases, they argue green entrepreneurs may require institutional structures that go beyond the standard-setting coalitions customary in many emerging industries. Meek et al. (2010) similarly argue that a broader institutional context influences sustainable entrepreneurship, where social norms favorable to sustainability objectives partially predict higher levels of new business formation.

Consistent with Lawrence and Suddaby's (2006) concept of institutional work, Lumpkin et al. (2013, p. 777-8) argue that entrepreneurs with social mandates often need to "break free from institutional norms and defy traditional approaches to problem-solving." Institutional work has been used to explore how strategy, practice work (actors' efforts to influence recognition and acceptance of routines), and boundary work (attempts to create, shape, and disrupt boundaries) are maintained or transformed within an organization (Lawrence et al. 2013; Zietsma and Lawrence 2010). For example, Van Dijk et al. (2011) examine how actors deploy institutional work to legitimize innovation within established firms, noting that ambiguity of interests, norms, and beliefs provide actors opportunities to spread new interpretations, gain legitimacy, and thus transform institutional systems in favor of the innovation.

According to Lawrence and Dover (2015), institutional work uses heterogeneous material and symbolic resources, which vary in availability and quality, affect the strategies actors employ, and by implication the 
heuristics used in decision-making. Lawrence et al. (2009) also caution that purposive shaping of institutions may result in significant unintended consequences, an area poorly understood. Finally, according to Lawrence et al. (2013), most studies on institutional work focus on intended outcomes based on retrospective analyses. Thus, while institutional work provides powerful strategic and theoretical perspectives for understanding and initiating institutional change, it currently lacks specific search heuristics that can be employed at early stages of development, issues we discuss next.

2.2 Mechanisms facilitating technological innovation for sustainability

Another theme in the entrepreneurship literature focuses on the role of technological innovation by green-tech ventures (Meyskens and Carsrud 2013). For example, O'Neil and Ucbasaran (2016) explore how legitimization processes of green entrepreneurs evolve to bring new technologies to new audiences. Technological innovation has been recognized as a key solution for addressing Grand Challenges (Hicks 2016; Reid et al. 2010) and more generally, a mechanism for transitioning towards more sustainable societies by correcting market failures (Markard et al. 2012; Wagner et al. 2014; York and Venkataraman 2010). Hockerts and Wüstenhagen (2010) argue that such transitions are often initially stimulated by new entrants that trigger responses from incumbents, moving the industry to the next level. The sustainability transitions literature thus focuses on multidimensional transformation processes (technological, institutional, political, economic) to promote more sustainable production and consumption (Markard et al. 2012).

According to Hess (2014, p. 279), the sustainability transitions literature does not explain the mechanisms that enable coalitions to achieve their goals under resistance from politically powerful incumbents. A more applied perspective that deals with such mechanisms is future technology analysis (FTA) that can guide practitioners' efforts to address Grand Challenges (Haegeman et al. 2013). FTA aligns with Clark and Wheelwright's (1993) seminal research on new product development, which emphasizes the importance of bringing technical and commercial knowledge about potential new products or processes together at early phases of development, the most efficient time to shape its innovation path. FTA does this by utilizing various technology foresight approaches that "values the multiplicity of perspectives, interests and knowledge held across a disperse landscape of actors and seeks to bring these together in processes of deliberation analysis and synthesis" (Cagnin and Keenan 2008, p. 4). Freeman and Soete (1997) and Martin (1994) have framed such perspectives under four areas of uncertainty: technological, commercial, organizational, and societal (TCOS).

Hall and Martin (2005) and Hall et al. (2011) suggest that managing these four areas of uncertainty requires the application of different heuristics. They argue that technological and commercial uncertainties can be understood using Popper's (1959) trial-and-error elimination scientific methodology approach. For societal uncertainties, there are often more stakeholders with varying opinions and goals that may not be appeased through purely scientific arguments, and as a result, heuristics based on Popper's (1945) piecemeal social engineering approach are more appropriate. According to York and Lenox (2014, p. 1930), sociocultural factors, the "... unwritten, decentralized rules of the game" play a particularly important role in green entrepreneurship. In addition to calling for different heuristics, the TCOS approach acts as a search tool, bringing together different technological, commercial, organizational, and societal perspectives at early phases of development, in an attempt to identify potential hurdles that must be overcome, or opportunities to exploit that may help legitimize the technology (Hall et al. 2011; 2014b).

According to Hall et al. (2014b), technological uncertainty focuses on overcoming scientific and engineering hurdles. As noted by Schumpeter (1934), invention (i.e., technological feasibility) requires a market transaction before it can be considered an innovation. Thus, commercial uncertainty deals with whether the new technology can successfully compete in the marketplace and can be improved with input from well-defined users involved during early stages of technology development (Clark and Wheelwright, 1993).

Organizational uncertainty focuses on whether, and how, organizations profit from the innovation, which, according to Teece (1986) and Martin (1994), is based on intellectual property (IP) protection, internal capabilities, and access to complementary assets. New ventures lacking complementary assets should either collaborate with or sell the technology to those that possess such assets. For university spin-offs, IP is often co-owned and managed by their technology transfer offices (TTOs), which were established to help academics 
commercialize inventions and transfer knowledge to practitioners (Siegel et al. 2004). TTOs typically first determine if the knowledge is patentable and then assess market potential (Feldman et al. 2002). This approach often negates technologies that are unsuitable for patenting such as when the potential market is small, or for applications that are suitable for "passive industries those that have limited resources and capabilities to seek out university research" (Hall et al. 2014b, p. 33).

Societal uncertainty deals with "the social impacts of the technology and how diverse social groups and secondary stakeholders may affect, or be affected by, its development" (Hall et al. 2014a, p. 99). Whereas TCO uncertainties are primarily concerned with establishing cognitive legitimacy, i.e. the knowledge needed to succeed in a new industry, socio-political legitimacy is the process by which key stakeholders accept a new venture given their existing norms (Aldrich and Fiol 1994), and is crucial for overcoming societal uncertainties. As discussed below, while establishing cognitive legitimacy is necessary, the core reason for a green-tech venture's existence resides with its socio-political legitimacy.

TCOS thus complements institutional work by providing a search tool that seeks to bring together the different perspectives and heuristics at early phases of development, the most efficient time to shape the innovation path of a new technology (Clark and Wheelwright 1993).

\section{Methodology}

We illustrate a detailed analysis of a University of British Columbia (Canada) potential green-tech venture, a spin-off from the "TAIGA" Project (Technological Aspects of Tree Aggressors Identification using Genomic Approaches) attempting to commercialize pathogen detection technology for forestry protection. Foreign pathogens are increasingly spread through international trade and exacerbated by climate change, resulting in major damage to forests and the industries that rely on them but can be reduced through early detection (Pimentel et al. 2000). To combat pathogen infestation, the International Plant Protection Convention (IPPC) provides international standards that are implemented through national plant protection agencies such as the Animal and Plant Health Inspection Service of the US Department of Agriculture and the Canadian Food
Inspection Agency (CFIA). Such agencies currently rely mostly on visual inspection, a problematic approach given that pathogens can be present before disease symptoms are visible, and cannot identify previously unknown pathogens (Hall et al. 2014b). TAIGA can improve regulatory risk assessments by testing genomic profiles of imported forest product samples against databases of known pathogens, thus eliminating costly false negatives and reducing false positives. Future generations of this technology may provide more immediate results, thus improving inspection efficiencies and facilitating proactive forest management.

We chose this case for several reasons. First, we respond to calls for further research on how entrepreneurship can facilitate sustainability (Hall et al. 2010; Hörisch et al. 2017), more specifically how R\&D can be translated into commercial applications through greentech ventures (Meyskens and Carsrud 2013) and how entrepreneurs bring new technologies to new audiences (O’Neil and Ucbasaran 2016). This case also provides insights on how university spin-offs can stimulate green technology. According to Meoli and Vismara (2016), university spin-offs have the potential to stimulate economic growth, but literature reviews on university spinoffs by Fryges and Wright (2014) and Grimaldi et al. (2011) indicate that few research projects have studied green technology, and none studied developing regulatory tools, as is the case here.

Second, consistent with the Grand Challenges (George et al. 2016; Hicks 2016; Reid et al. 2010) and sustainability transitions literature (Hess 2014; Markard et al. 2012; Musiolik et al. 2012; Penna and Geels 2012), this technology can potentially improve international standards for forestry protection by offering faster and more accurate assessments but requires transformational processes in risk assessment practices. Finally, data from multiple sources on TAIGA's challenges and opportunities allow us to explore the experimental and green technology developmental process under "extreme circumstances" (Eisenhardt and Graebner 2007). All of these factors make TAIGA a relevant case (Yin 1994).

Using a single case study was appropriate and instrumental because qualitative case studies can support and facilitate comprehension of phenomena that are not well understood (Marshall and Rossman 1995) and further develop existing theory "by pointing to gaps and beginning to fill them" (Siggelkow 2007, p. 21). Case studies 
can also tease out specific mechanisms underlying entrepreneurship processes (Maguire et al. 2004).

We identified key stakeholders as potential interviewees from desk research and suggestions provided by TAIGA scientists and other stakeholders identified through the snowball technique (Berg 1988). We interviewed 68 people between December 2011 and November $2013,{ }^{1}$ with expertise on scientific, policy, and business-oriented issues. To ensure data triangulation (Yin 1994), we interviewed representatives from different areas and levels within organizations and stakeholders with varying perspectives from Canada, US, Japan, New Zealand, Australia, Italy, and the UK. Such geographical variation helped us explore potential international implications on standards and plant protection protocols in trade agreements.

Our units of analysis are potential green-tech entrepreneurs developing the TAIGA technology. Our level of analysis is the process by which (i.e., how) engaging in institutional work can change government risk assessment practice in favor of technology adoption. Data collection and analysis interacted throughout the research process, allowing for deductive and inductive coding using TCOS as an organizing framework and search tool. We searched for heterogeneous material and symbolic resources (Lawrence and Dover 2015) at an early stage of the technology's development, thus providing the potential green-tech venture with strategic options. For example, introductory questions related to stakeholders' perceptions of key forestry industry issues were followed by an open discussion on potential TCOS challenges (i.e., hurdles that need to be overcome) and opportunities (i.e., levers that can be exploited) related to the adoption of the TAIGA technology (interview protocol guide provided in Appendix 2). We transcribed and coded interviews using the qualitative data analysis software Atlas.ti.

Following Miles and Huberman's (1994) deductive process, stakeholder quotes were first organized according to themes and subthemes from the TCOS search. As the analysis progressed, additional subthemes emerged inductively, such as "stakeholder take up" and "cost sensitivity." Two researchers coded the transcripts to ensure inter-rater reliability. The coding system table and samples of quotes linked to code themes are

\footnotetext{
${ }^{1}$ Interview subjects are listed in Appendix 1, and an update of what happened to the TAIGA project as of May 2017 is available in Appendix 4 (both available as electronic supplementary material).
}

presented in Appendix 3. Finally, we went back to the theory and used institutional work to synthetize the TCOS findings into an understanding of how greentech entrepreneurs can have an active role in changing regulatory practices for the benefit of technological diffusion.

\section{Analysis}

We next analyze our findings using TCOS as an organizing framework, starting with the $\mathrm{T}, \mathrm{C}$, and $\mathrm{S}$ analyses derived from our search process outlined in the methodology. We conclude with the $\mathrm{O}$ analysis, which, combined with the other analyses, provides insights on suitable business models for the proposed green-tech venture.

\subsection{Technological analysis}

Proof of concept for the TAIGA technology has been established, where Canadian regulators successfully used similar genomics-based pathogen detection tools during the Sudden Oak Death pathogen outbreak. According to a CFIA representative, "[Scientists] showed how the Sudden Oak Death test gave less or no false positives compared to some of the other types of tests that we're doing. The DNA-based tests [have fewer] false positives." TAIGA thus provides an important value proposition needed in forestry by improving accuracy.

A key lever of TAIGA is to simplify risk assessments (Fig. 1) and address biosecurity issues - "it simplifies things enormously" according to a New Zealand plant protection organization representative. An industry representative stated, "if there are known problems and this is a simple tool for detecting known problems, it streamlines the process rather than complicating it." Canadian provincial forest managers were similarly interested in future applications capable of on-site testing and verification, facilitating more proactive risk management: "If we could get the equipment and do the testing ourselves, I think that would be ideal."

Key technological issues include false positives and negatives “... an absolutely massive risk, especially around the world of pathogens..." commented a Provincial Policy representative. TAIGA is a significant improvement over visual inspections reducing cases of false negatives. However, given that it is much more 
Current method

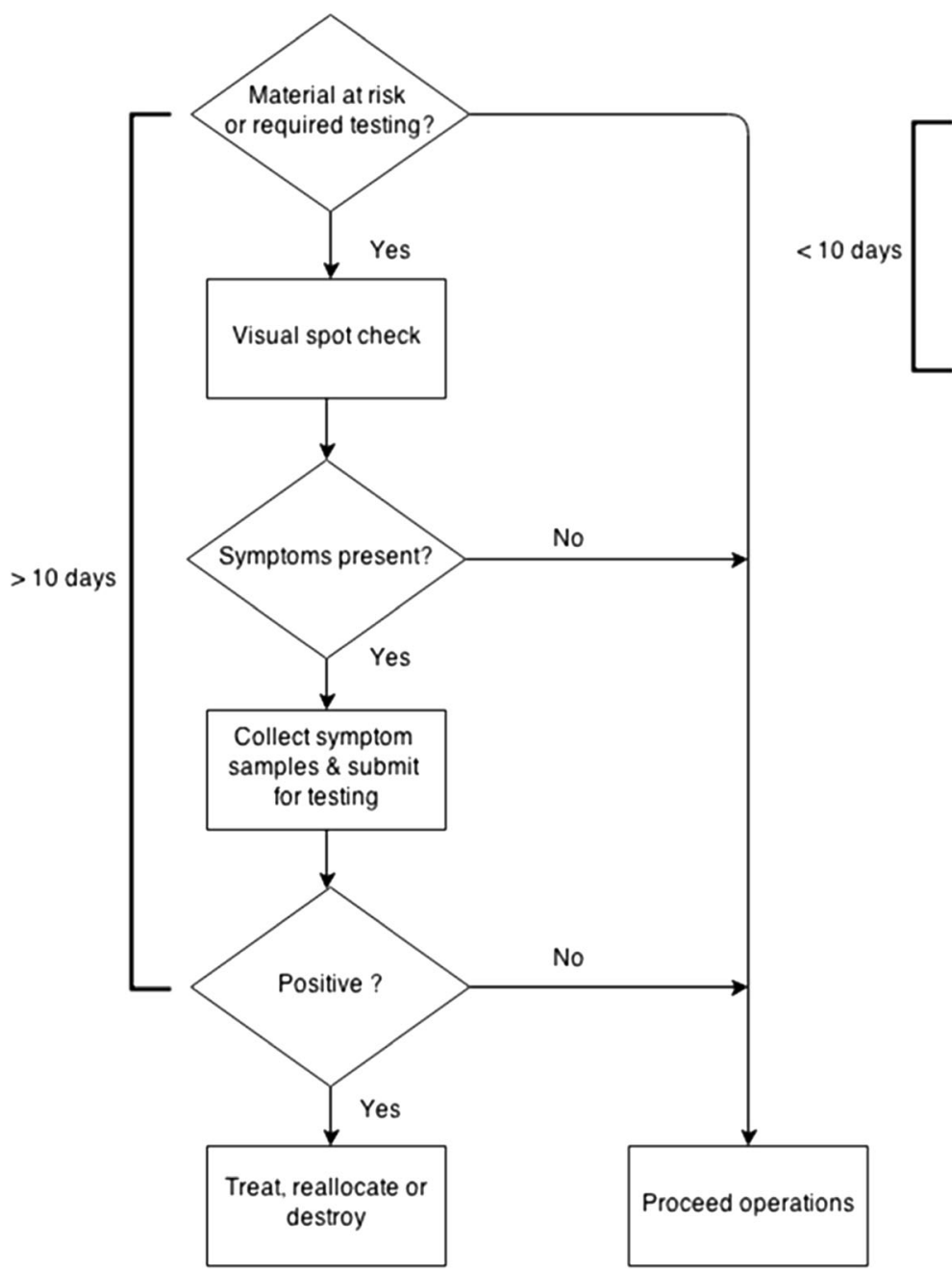

TAIGA method

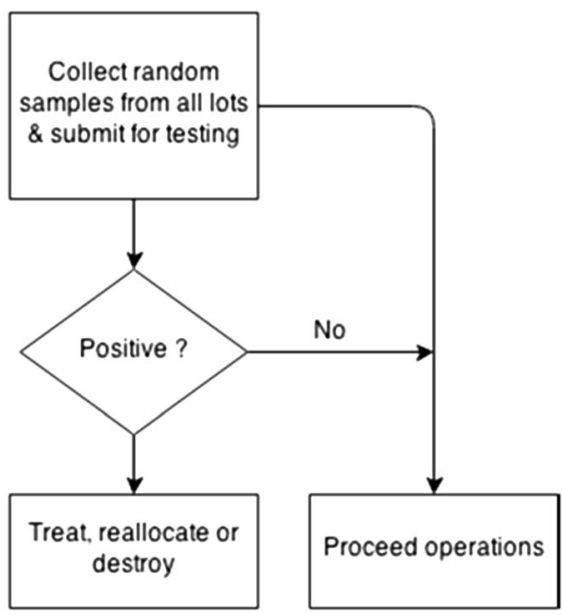

Fig. 1 Risk assessment practice benchmark

sensitive, there were concerns that it may detect minute traces of pathogens that may not warrant quarantine or dead (and therefore harmless) pathogens, resulting in false positives. A CFIA scientist noted, "we do have viability tests that we do to see if the organism is alive and functional... DNA might not give us the answer if we're looking to see if something's alive."

Interpreting the diagnostic test results is also crucial. According to a National Policy representative, "detecting it is one thing, proving that it's making some harm to the forest is another thing" and "... if it is a tool that tells you a positive or negative and then maybe spits out a name or something, there's a huge wealth of information that needs to go before and after that to say, 'What is that really in that situation?" Concerns are thus more about how the information will be used rather than the technology per se. Its utility will thus need to be closely entwined with guidelines, operating procedures, and limitations.

\subsection{Commercial analysis}

Following Clark and Wheelwright (1993), the TAIGA team engaged with potential early users in order to understand their needs and concerns. Regulators were identified as the first users, and the CFIA collaborated with TAIGA throughout the project. Possible secondary markets included private forest industry users such as nurseries and lumber exporters seeking improved forest management tools. 
Regulators actively encouraged improved pathogen detection technology due to the significant commercial benefits from avoiding outbreaks. For example, the Sudden Oak Death infestation inflicted an estimated $\$ 580$ million in damages on British Columbia forestry industries (Elliott et al. 2012). A New Zealand Government Policy representative stated “....anything that's going to enhance our sensitivity around detecting pathogens coming into New Zealand will get picked up by us very, very quickly."

Potential increased trade through more reliable detection practices was also identified as a key lever. A CFIA representative stated "The more trade that we do, the more the other countries ask us to ensure that the products that we are exporting from Canada are free from specific pathogens... that's where these DNA-based tests will be valuable...." Industry representatives had similar views: "I know that there definitely have been trade barrier issues around potential pathogens..., so something like this could be of use." An industry association representative noted the importance of non-tariff trade barriers around phytosanitary testing, "It's a difficult thing for us to be able to, with certainty, demonstrate to our customers in a foreign government that the lumber that we're shipping ... does not contain those kinds of pathogens. So would be extremely useful." However, this interviewee also emphasized "It's got to be able... to test it in some cost effective way.... you can't test every stick, obviously. So how it gets commercialized would be very important as well."

While end users were clearly engaged, their willingness to pay was more ambiguous. For example, there was little awareness about the full costs of incumbent detection methods, with estimates ranging from $\$ 15$ to $\$ 200$ per sample per test. A CFIA representative stated "[I]n a government agency, there isn't really a bottom... Well, there is a bottom line, but it's not determined, it's not based on business decisions really. So I can't increase the cost of my something-or-other to help cover off the cost of this other test." Thus, current pathogen detection costs are incorporated as part of other operating expenses, "there's layers of investment in terms of infrastructure, people, expertise and diagnostic procedures within CFIA... But if you're looking at the forestry pathogen, that's a narrow slice of that overall testing investment."

While regulators were unable to estimate costs for their incumbent detection methods, they expected detailed estimates about TAIGA costs. According to all interviewees, the commodity-driven forestry sector is cost-sensitive and often reactive to phytosanitary issues. For example, an industry representative lamented about the pressures to be efficient under increasing grading rules, regulations, building codes, etc., "... and then the phytosanitary is just on top of all that." According to a nursery operator, "Cost effective is huge... it has to have reasonableness in terms of how much sampling needs to be done."

Interviewees also acknowledged potential trade restrictions. An International Policy representative stated, "There are some who would use or misuse such [DNABased] evidence more or less for the purpose of erecting an artificial trade barrier." According to one Municipal representative, "Trade is often politically minded... I don't think a better diagnostic tool would protect you from a political backlash of closing a commodity off simply because of... the hint of pathogen...." According to a CFIA representative, "We can promote a technology to our trading partners and say, 'We have a lot of confidence in our ability to certify your export using this technology...' but if that country doesn't accept this technology or our arguments and our evidence..., then we can't use it." Establishing legitimacy is thus crucial.

\subsection{Societal analysis}

TAIGA is primarily intended to improve forest protection and provide additional benefits such as improved information on biodiversity and climate change management. Awareness about advanced approaches varied among stakeholders, but overall, most supported the technology. All interviewees from national plant protection agencies and the IPPC valued DNA-based assessment tools, although there was some skepticism about accuracy. Support from the IPPC and national plant protection organizations can thus establish legitimacy.

Representatives from environmental and aboriginal groups generally supported the technology, particularly since it could provide better risk assessment information. However, some expressed concerns over transparency and how information would be managed. The United Nations Convention on Biodiversity recognizes climate change adaptation and biodiversity protection from pest outbreaks as critical (Termorshuizen and Opdam 2009). Climate change is expected to have an impact on tree infestations (IPCC 2014). More effective monitoring is thus needed (Boyd et al. 2013), which can be facilitated by TAIGA. Secondary stakeholders 
strongly support climate change applications, "I could definitely see, especially as climate change progresses, that this may be a good tool for diagnostics [to assess]... ecosystems."

Some stakeholders suggested the Convention on Biological Diversity (CBD) as a potential lever for improved pathogen detection technology: "It's possible that governments, as they... start to implement and use the CBD more will see [TAIGA] as one of the tools that will allow them to better meet some of the CBD goals" noted an International Policy representative. Canada ratified the $\mathrm{CBD}$ and is obligated to fulfilling biodiversity management objectives by taking all necessary steps to prevent the introduction of harmful alien organisms and mitigate or eliminate their adverse effects through better monitoring (Lindgren 2012). Technologies that help manage biodiversity will thus be useful for Canadian policymakers.

\subsection{Organizational analysis}

The TAIGA team has access to complementary assets such as technical knowledge and testing equipment, an extensive network, and a strong reputation with regulators through their Sudden Oak Death test used by the CFIA. However, the developers, as academics, have limited experience operating for-profit businesses and IP management.

Consistent with Feldman et al. (2002), the university's TTO officer stated their limited resources dictate prioritizing projects that are applicable to potentially large markets and patentable, as this is a relatively straightforward contractual process understood by both users and producers. While gene discovery is patentable in Canada, in the USA, the isolation of genes without any alteration of genetic information is not considered an act of invention. ${ }^{2}$ Given the importance of the US market to Canadian forestry trade, patent protection for TAIGA seems unviable or at best would be mired in legal uncertainties and as a result, would have difficulties meeting the TTO's threshold.

An alternative to patenting possibly suitable for TAIGA is to use trade secrets. However, TAIGA's funding agency rewards patents as a proxy for success, while researchers are also under pressure to publish, which

\footnotetext{
$\overline{{ }^{2} \text { See Appendix }} 5$ (electronic supplementary material) for a summary of the gene discovery patents and trade secrets.
}

conflicts with secrecy, a common challenge of commercializing university research (Czarnitzki et al. 2014).

As discussed above, the initial market is estimated to be small, although there are longer-term market opportunities with greater international adoption and diversification into other areas such as agriculture. One method of appropriating these longer-term profits is by creating a standard (Teece 1986), which creates a competitive advantage such that users of the standard would consider TAIGA technology first.

Being instrumental in creating a standard can create first-mover advantages and, given the limited global market size, result in a "winner-takes-all" scenario, where capturing the market majority leaves the remaining market too small to warrant a competitive response. However, the decision to adopt specific technology is made nationally. An IPPC technical standards specialist noted that it can cost millions to establish a standard diagnostic tool for an international commodity, “... this can cause some uncomfortable situations regarding facilities and really implementing and making this as a standard, as a minimal requirement for diagnostics." Trading partners are also allowed to challenge the test findings if they resulted in import rejections.

We speculate that if one regulator adopts TAIGA and it is proven to offer greater efficacy, other regulators will follow. The TAIGA team therefore needs to develop a business model that includes institutional work that will specifically engage with the CFIA, IPPO, and other regulatory bodies, to work with, rather than rely on the standard practices of the TTO.

\section{Discussion and conclusions}

We respond to calls for more in-depth research on entrepreneurship for sustainable development (Hörisch et al. 2017), particularly the challenges of bringing green technologies to new audiences (O'Neil and Ucbasaran 2016) and finding commercial applications through green-tech ventures (Criscuolo and Menon 2015; Kesidou and Demirel 2012; Meyskens and Carsrud 2013). Our analysis also provides insights for understanding the panacea hypothesis of green entrepreneurship (Hall et al. 2010) by going beyond opportunity identification of market imperfections (Cohen and Winn 2007; Dean and McMullen 2007; York and Venkataraman 2010) to explore the challenges and nuances of actually converting green technologies into 
green innovations. We do so by building on Meek et al.'s (2010) and Pacheco et al.'s (2010) recognition of institutional environments influencing green-tech ventures but explicitly emphasizing that entrepreneurs may need to actively shape their institutional environment (Lumpkin et al. 2013), especially for green-tech ventures (Farla et al. 2012). We thus draw on institutional work (Lawrence et al. 2013; Zietsma and Lawrence 2010) to understand how entrepreneurs influence institutional change, in this case, through the adoption of more effective regulatory risk assessment practices.

To answer our question how entrepreneurs engage in institutional work to transition green technology into green innovation, we presented a theoretical framework that combines institutional work with the TCOS framework of innovative uncertainties that explicitly searches for key technological, commercial, organizational, and societal issues that may affect diffusion. Thus, while institutional work recognizes that entrepreneurs may have to influence institutional change, TCOS identifies the specific issues and stakeholder concerns that need to be considered, at which point strategies can be developed to deal with them.

We contribute towards institutional work in numerous ways. First, we respond to Lawrence et al.'s (2013) observation that most studies on institutional work focus on retrospective analyses, by studying a green-tech venture at an early stage of development. Similar to van Dijk et al. (2011), we found the TAIGA project has an opportunity to engage in institutional work aiming to diffuse innovation within organizations. We however add to previous studies by emphasizing that institutional work could be a main activity for a green-tech venture. We thus differ from much of the literature by placing institutional work as a core entrepreneurial strategy rather than as an afterthought. We also responded to concerns by Lawrence et al. (2009) regarding unintended consequences when agents engage in purposive institutional shaping, by utilizing TCOS as a search tool at early stages of technology development. We were thus able to identify potential unintended consequences, such as misuse of TAIGA technology for restricting trade, which could hinder the technology's adoption.

A key issue in the literature is the need to establish legitimacy (Aldrich and Fiol 1994; Hall et al. 2014a; Van Dijk et al. 2011), especially for new firms engaging with regulators (Carpenter 2004). While establishing cognitive legitimacy is clearly necessary, we suggest the core purpose of a green-tech venture resides in its socio-political legitimacy. The TCOS analysis found the key challenges facing TAIGA are primarily non-technical. We therefore address calls for more research on coordinated and collaborative effort advocated in the Grand Challenges (George et al. 2016) and sustainability transitions literatures (Farla et al. 2012) by emphasizing the need for search mechanisms to facilitate institutional work and identify potential unanticipated outcomes that may hinder green innovation.

\subsection{Recommendations}

Greater awareness of the technology's ability to address more stringent phytosanitary procedures and improved climate change and biodiversity management would likely establish socio-political legitimacy. However, concerns over how information derived from the technology would be used, particularly regarding international trade disputes, could hamper adoption. The commercial viability of the technology also presents challenging circumstances, given the primary initial users will be regulators that, according to our interviews, are concerned about how much the technology may cost but lack data on cost structures for incumbent procedures. Forestry industry representatives similarly raised concerns over added costs, noting the industry is usually financially constrained and reactive to phytosanitary issues.

Given these circumstances, a main activity of the venture would be to engage in institutional work to complement the specific technologies being developed by TAIGA. This could include a comprehensive set of technical procedures, ongoing guidelines, and operating boundaries explaining how to use the information derived from the technology. The venture must also engage in regulatory change, specifically convincing regulators to adopt the more effective risk assessment procedures offered by TAIGA, and provide insights derived from the TCOS analysis on the implications it may have on industry and international trade. The key issue for green-tech ventures is that moving from green technology development to green innovation involves considerable institutional work, and as such, should be reflected in the business model.

The organizational analysis found that patenting is infeasible given the initial market will likely be insufficient to cover extensive IP protection and governance costs. While trade secrets may be a valid alternative, 
academic TAIGA team members have to reconcile conflicting pressures for IP protection with pressures to publish (Czarnitzki et al. 2014). However, the small market may allow for the establishment of an industry standard. The venture could therefore commercialize the first generation of TAIGA at no/minimal cost to the CFIA in an attempt to establish legitimacy, with a long-term objective of making it the international standard. To do so, the venture must actively engage in institutional work to establish legitimacy and reconcile ambiguity of interests, norms, and beliefs that may otherwise hinder the innovation's diffusion (van Dijk et al. 2011), particularly the interface between phytosanitary regulations and international trade. Ultimately, we believe the real value of the proposed venture will be derived from the "software" (i.e., how the information is interpreted and the institutional work that stimulates institutional change towards more effective forestry protection) rather than the "hardware" (i.e., the specific DNA-based assessment tools).

\subsection{Limitations and further research}

As a single case study, our research is limited by what can be generalized. While our proposed green-tech venture provided insights on issues recognized by the green entrepreneurship and institutional work literature, comparative studies could add additional insights. For example, considering different jurisdictions as first adopters, and other industrial sectors such as agriculture, could account for how differences in economic and political systems influence institutional work at nascent stages of green-tech ventures. While the majority of green entrepreneurship literature recognizes the importance of policy in green innovation, few focus on shaping institutions as a core function of green-tech ventures. It would therefore be useful to determine under what circumstances institutional work is required and when a passive role is sufficient.

Another area for further research is how ambiguity of interests, norms, and beliefs (van Dijk et al. 2011) may result in unintended detrimental outcomes (Lawrence et al. 2013) and more specifically, how various stakeholders choose to interpret information that may prevent societally beneficial technology from diffusing. Given potential controversial trade implications, we speculate that some stakeholders may, for example, choose to resist the technology for one reason (e.g., trade protection) but justify their actions with other reasons (e.g., potential for false positives).

Developing an international industry standard will likely create further demand for informational services and may stimulate more proactive behavior by regulators and the forest industry. Further applied research could explore how to stimulate other applications, for example, in private forest management and the much larger (and controversial) agricultural sector. Shifting towards a proactive orientation is difficult, especially given the sector's cost sensitivities. Experiences from the quality assurance movement and recent trends in environmental management could provide useful analogies that can be communicated to industry. Another potentially useful analogy is the insurance industry, for example, where firms pay the cost (premiums) for testing as protection to reduce the likelihood of a costly future discovery.

Acknowledgements Funding for this research was supplied by Genome Canada, Genome British Columbia, and the Social Science and Humanities Research Council of Canada. We would like to acknowledge the contributions of our colleagues, Robin Downey, Richard Hamelin, Hesther Lui, Adnan Uzunovic, Déborah Farias, and Stephan Brière, as well as those that participated in the research and the useful comments from the reviewers and special issue editors.

Open Access This article is distributed under the terms of the Creative Commons Attribution 4.0 International License (http:// creativecommons.org/licenses/by/4.0/), which permits unrestricted use, distribution, and reproduction in any medium, provided you give appropriate credit to the original author(s) and the source, provide a link to the Creative Commons license, and indicate if changes were made.

\section{References}

Aldrich, H., \& Fiol, M. (1994). Fools rush in? The institutional context of industry creation. Academy of Management Review, 19(4), 645-670.

Berg, S. (1988). Snowball sampling. In S. Kotz and N. Johnson (Ed.), Encyclopedia of Statistical Sciences (8th ed.)

Boyd, I., Freer-Smith, P., Gilligan, C., \& Godfray, H. (2013). The consequence of tree pests and diseases for ecosystem services. Science, 342(6160), 123577.3-123577.7.

Bruton, G., Ahlstrom, D., \& Han-Lin, L. (2010). Institutional theory and entrepreneurship: where are we now and where do we need to move in the future? Entrepreneurship: Theory \& Practice, 34(3), 421-440.

Cagnin, C., \& Keenan, M. (2008). Positioning future-oriented technology analysis. In Future-Oriented Technology Analysis. Springer Berlin Heidelberg. 
Carpenter, D. (2004). Protection without capture: product approval by a politically responsive, learning regulator. American Political Science Review, 98(04), 613-631.

Clark, K., \& Wheelwright, S. (1993). Managing new product and process development: text and cases. NY: Free Press.

Cohen, B., \& Winn, M. (2007). Market imperfections, opportunity and sustainable entrepreneurship. Journal of Business Venturing, 22(1), 29-49.

Criscuolo, C., \& Menon, C. (2015). Environmental policies and risk finance in the green sector: cross-country evidence. Energy Policy, 83, 38-56.

Czarnitzki, D., Rammer, C., \& Toole, A. (2014). University spinoffs and the 'performance premium'. Small Business Economics, 43(2), 309-326.

Dean, T., \& McMullen, J. (2007). Toward a theory of sustainable entrepreneurship: reducing environmental degradation through entrepreneurial action. Journal of Business Venturing, 22(1), 50-76.

Eisenhardt, K., \& Graebner, M. (2007). Theory building from cases: opportunities and challenges. Academy of Management Journal, 50(1), 25-32.

Elliott, M., Shamoun, S., \& Chastagner, G. (2012). An overview of the Sudden Oak Death (SOD) disease caused by Phytophthora ramorum: research results and challenges for the Pacific Northwest of North America. Canadian Forest Service, http://cfs.nrcan.gc.ca/publications?id=34143.

Farla, J., Markard, J., Raven, R., \& Coenen, L. (2012). Sustainability transitions in the making: a closer look at actors, strategies and resources. Technological Forecasting and Social Change, 79(6), 991-998.

Feldman, M., Feller, I., Bercovitz, J., \& Burton, R. (2002). Equity and the technology transfer strategies of American research universities. Management Science, 48(1), 105-121.

Freeman, C., \& Soete, L. (1997). The economics of industrial innovation. Cambridge, MA: MIT.

Fryges, H., \& Wright, M. (2014). The origin of spin-offs: a typology of corporate and academic spin-offs. Small Business Economics, 43(2), 245-259.

George, G., Howard-Grenville, J., Joshi, A., \& Tihanyi, L. (2016). Understanding and tackling societal grand challenges through management research. Academy of Management Journal, 59, 1880-1895.

Grimaldi, R., Kenney, M., Siegel, D. S., \& Wright, M. (2011). 30 years after Bayh-Dole: reassessing academic entrepreneurship. Research Policy, 40(8), 1045-1057.

Haegeman, K., Marinelli, E., Scapolo, F., Ricci, A., \& Sokolov, A. (2013). Quantitative and qualitative approaches in futureoriented technology analysis (FTA): from combination to integration? Technological Forecasting and Social Change, 80(3), 386-397.

Hall, J., Daneke, G., \& Lenox, M. (2010). Sustainable development and entrepreneurship: past contributions and future directions. Journal of Business Venturing, 25(5), 439-448.

Hall, J., \& Martin, M. (2005). Disruptive technologies, stakeholders and the innovation value-added chain: a framework for evaluating radical technology development. $R \& D$ Management, 35(3), 273-284.

Hall, J., Bachor, V., \& Matos, S. (2014a). Developing and diffusing new technologies: strategies for legitimization. California Management Review, 56(3), 98-117.
Hall, J., Matos, S., Bachor, V., \& Downey, R. (2014b). Commercializing university research in diverse settings: moving beyond standardized intellectual property management. Research-Technology Management, 57(5), 26-34.

Hall, J., Matos, S., Silvestre, B., \& Martin, M. (2011). Managing technological and social uncertainties of innovation: the evolution of Brazilian energy and agriculture. Technological Forecasting and Social Change, 78(7), 1147-1157.

Hess, D. J. (2014). Sustainability transitions: a political coalition perspective. Research Policy, 43(2), 278-283.

Hicks, D. (2016). Grand Challenges in US science policy attempt policy innovation. International Journal of Foresight and Innovation Policy, 11(1-3), 22-42.

Hockerts, K., \& Wüstenhagen, R. (2010). Greening Goliaths versus emerging Davids - theorizing about the role of incumbents and new entrants in sustainable entrepreneurship. Journal of Business Venturing, 25(5), 481-492.

Hörisch, J., Kollat, J., \& Brieger, S. (2017). What influences environmental entrepreneurship? A multilevel analysis of the determinants of entrepreneurs' environmental orientation. Small Business Economics, 48(1), 47-69.

IPPC: Intergovernmental Panel on Climate Change. (2014). Chapter 11 Agriculture, forestry and other land use (AFOLU). Climate Change 2014: Mitigation of Climate Change (811-922). https://www.ipcc.ch/pdf/assessmentreport/ar5/wg3/ipcc_wg3_ar5_full.pdf

Kesidou, E., \& Demirel, P. (2012). On the drivers of eco-innovations: empirical evidence from the UK. Research Policy, 41(5), 862-870.

Lawrence, T., \& Dover, G. (2015). Place and institutional work creating housing for the hard-to-house. Administrative Science Quarterly, 60(3), 371-410.

Lawrence, T., Leca, B., \& Zilber, T. (2013). Institutional work: current research, new directions and overlooked issues. Organization Studies, 34(8), 1023-1033.

Lawrence, T., \& Suddaby, R. (2006). Institutions and institutional work. In S. Clegg, C. Hardy, T. Lawrence, \& W. Nord (Eds.), The SAGE handbook of organization studies (pp. 215-254). Thousand Oaks, CA: Sage.

Lawrence, T., Suddaby, R., \& Leca, B. (2009). Institutional work: actors and agency in institutional studies of organizations. Cambridge University Press.

Lindgren, C. (2012). Biosecurity policy and the use of geospatial predictive tools to address invasive plants: updating the risk analysis toolbox. Risk Analysis, 32(1), 9-15.

Lumpkin, G., Moss, T., Gras, D., Kato, S., \& Amezcua, A. (2013). Entrepreneurial processes in social contexts: how are they different, if at all? Small Business Economics, 40(3), 761783.

Maguire, S., Hardy, C., \& Lawrence, T. (2004). Institutional entrepreneurship in emerging fields: HIV/AIDS treatment advocacy in Canada. Academy of Management Journal, 47(5), 657-679.

Markard, J., Raven, R., \& Truffer, B. (2012). Sustainability transitions: an emerging field of research and its prospects. Research Policy, 41(6), 955-967.

Marshall, C., \& Rossman, G. (1995). Designing qualitative research. In J. M. Morse (Ed.), Critical issues in qualitative research methods. Thousand Oaks, CA: Sage.

Martin, M. (1994). Managing innovation and entrepreneurship in technology based-firms. NY: Wiley. 
Meek, W., Pacheco, D., \& York, J. (2010). The impact of social norms on entrepreneurial action: evidence from the environmental entrepreneurship context. Journal of Business Venturing, 25(5), 493-509.

Meoli, M., \& Vismara, S. (2016). University support and the creation of technology and non-technology academic spinoffs. Small Business Economics, 47(2), 345-362.

Meyskens, M., \& Carsrud, A. (2013). Nascent green-technology ventures: a study assessing the role of partnership diversity in firm success. Small Business Economics, 40(3), 739-759.

Miles, M., \& Huberman, M. (1994). Qualitative data analysis. Thousand Oaks, CA: Sage.

Musiolik, J., Markard, J., \& Hekkert, M. (2012). Networks and network resources in technological innovation systems: towards a conceptual framework for system building. Technological Forecasting and Social Change, 79(6), 1032-1048.

O’Neil, I., \& Ucbasaran, D. (2016). Balancing "what matters to me" with "what matters to them": exploring the legitimation process of environmental entrepreneurs. Journal of Business Venturing, 31(2), 133-152.

Pacheco, D., Dean, T., \& Payne, D. (2010). Escaping the green prison: entrepreneurship and the creation of opportunities for sustainable development. Journal of Business Venturing, 25(5), 464-480.

Penna, C., \& Geels, F. (2012). Multi-dimensional struggles in the greening of industry: a dialectic issue lifecycle model and case study. Technological Forecasting and Social Change, 79(6), 999-1020.

Pimentel, D., Lach, L., Zuniga, R., \& Morrison, D. (2000). Environmental and economic costs of nonindigenous species in the United States. Bioscience, 50(1), 53-65.

Pirnay, F., \& Surlemont, B. (2003). Toward a typology of university spin-offs. Small Business Economics, 21(4), 355-369.

Popper, K. (1945). The open society and its enemies. Abingdon: Routledge.

Popper, K. (1959). The logic of scientific discovery. London: Hutchinson.

Reid, W., Chen, D., Goldfarb, L., Hackmann, H., Lee, Y., Mokhele, K., Ostrom, E., Raivio, K., Rockström, J.,
Schellnhuber, H., \& Whyte, A. (2010). Earth system science for global sustainability: grand challenges. Science, 330(6006), 916-917.

Schumpeter, J. (1934). The theory of economic development: an inquiry into profits, capital, credit, interest, and the business cycle. Cambridge, MA: Harvard University Press.

Siegel, D., Waldman, D., Atwater, L., \& Link, A. (2004). Toward a model of the effective transfer of scientific knowledge from academicians to practitioners: qualitative evidence from the commercialization of university technologies. Journal of Engineering \& Technology Management, 21(1), 115.

Siggelkow, N. (2007). Persuasion with case studies. Academy of Management Journal, 50(1), 20-24.

Teece, D. (1986). Profiting from technological innovation. Research Policy, 15(6), 285-305.

Termorshuizen, J., \& Opdam, P. (2009). Landscape services as a bridge between landscape ecology and sustainable development. Landscape Ecology, 24(8), 1037-1052.

van Dijk, S., Berends, H., Jelinek, M., Romme, A., \& Weggeman, M. (2011). Micro-institutional affordances and strategies of radical innovation. Organization Studies, 32(11), 14851513.

Wagner, M., Bachor, V., \& Ngai, E. (2014). Engineering and technology management for sustainable business development: introductory remarks on the role of technology and regulation. Journal of Engineering and Technology Management, 34, 1-8.

Yin, R. (1994). Case study research: design and methods (2nd ed.). Thousand Oaks, CA: Sage.

York, J., \& Lenox, M. (2014). Exploring the sociocultural determinants of de novo versus de alio entry in emerging industries. Strategic Management Journal, 35(13), 1930-1951.

York, J., \& Venkataraman, S. (2010). The entrepreneur-environment nexus: uncertainty, innovation, and allocation. Journal of Business Venturing, 25(5), 449-463.

Zietsma, C., \& Lawrence, T. (2010). Institutional work in the transformation of an organizational field: the interplay of boundary work and practice work. Administrative Science Quarterly, 55(2), 189-221. 